\title{
Constitution-Making Dispute Resolution Mechanisms: Lessons from Kenya
}

\author{
Dr John Mukuna
}

\author{
Senior Lecturer, Botswana Accountancy College
}

Email: johnm@bac.ac.bw

\section{Professor Melvin LM Mbao}

Executive Dean and Professor of Public Law and Legal Philosophy, North West University, South Africa

Email:Melvin.Mbao@nwu.ac.za

\section{Doi:10.5901/mjss.2014.v5n23p727}

\begin{abstract}
This article examines the Constitution-making dispute mechanism in relation to the making of the 2010 of Kenya. What forcefully triggered the process of constitution-making was the 2007-2008 post-election violence which was brought to an end by the efforts of the Kofi-Annan dialogue and reconciliation initiatives. Of the several issues which required urgent attention so as to restore peace and order, the central item was the commencement of constitutional reforms which had stalled in the past. While the relevant statutory infrastructure in form of the Constitution of Kenya Review Act 2008 was established, the Act failed to address the manner in which disputes arising from the process of constitution-making would be settled in spite that at the time, the judiciary was generally an appendage of the executive. Later, an amendment to the Constitution was made which established the ad hoc Interim Independent Constitution Dispute Resolution Court (IICDRC). Notwithstanding the political climate then prevailing, there was no haste in the operationalization of the Court. After the Court commenced its work, it made some decisions which this paper considers a grave misdirection of the law thus denying itself an opportunity to fully determine the legitimacy of the draft constitution and thereby the 2010 Constitution of Kenya. The paper recommends that dispute settlement mechanisms and related matters should be fully integrated in constitution-making or reform enterprise.
\end{abstract}

Keywords: Constitution, rule of law, legitimacy, reforms, judiciary.

\section{Introduction}

The road towards the 2010 Constitution of Kenya was a strenuous and painful one as evidenced by the unfettered violation of human rights of those involved in the struggle (Mutunga, 1999; Throup \& Harnsby, 1998; Wanyande, Omosa \& Ludeki (2007; Mejia, 1995; Murunga \& Nasong'o, 2006). After the National Rainbow Coalition (NARC) opposition victory in 2002, there were high expectations that the Mwai Kibaki-led government would commence meaningful and genuine constitutional reforms in earnest. That was not to be and by the end of his first term in 2007, the country was still under a Constitution which favoured an authoritarian presidency. This must have exacerbated the unprecedented wave of violence which emerged after the announcement of Kibaki as the winner. The intervention of the African Union through the Kofi-Annan led initiative termed the Kenya National Dialogue and Reconciliation (KNDR) rescued the country from collapse by striking of a power sharing deal between former opposition coalition partners, Mwai Kibaki and Raila Odinga (KNDR, 2009). The central agenda item of the KNDR was legal reforms in particular a new constitution for the country. Relevant legislation were passed to commence the process and in this regard, our main focus in this article is the Constitution of Kenya Review Act, 2008 (herein the 'Review Act').

The Review Act's philosophy especially section 4 was a constitution-making framework which could change the political direction of the country by among others embracing public participation in the affairs of state. One fundamental item which was overlooked in the new constitution-making agenda was how disputes arising from the exercise could be resolved. At the time, perhaps, the assumption was that the judiciary could deal with any challenge on the new project. However, it soon became clear that the Kenyan judiciary had major weaknesses which dented its image and credibility as an independent arbiter. This reality led to a hasty process of amending the Constitution to create the Interim Independent Constitutional Dispute Resolution Court (IICDRC).

However, it took what under the circumstances was unreasonable time for the court to be operationalized. After the court commenced its work, it made some pronouncements of the law which we consider inconsistent with the doctrine of 
supremacy of the constitution and a contemporary view of the rule of law. We attribute this outcome to the absence of diligence in establishing the court and generally in not according substantial weight and regard to dispute resolution mechanism as key in constitution-making initiatives. We argue that the judiciary could not be trusted with the enormous task of settling disputes arising from the constitution-making process because it was tormented by myriad challenges for instance corruption (Kwach Report, 1998; Ringera Report, 2003; International Commission of Jurists, 2005); executive control (Mutua, 2001) and a restrictive and legalistic interpretation of legislation which is a great impediment to the development of the law (M'Inoti, 2003; Hoexter, 2004). Instead of the courts being the bulwark against violation of human rights, they generally appeared to ignore basic constitutional guarantees of rights and freedoms (Kuria \& Vazquez, 1993). These factors significantly contributed to loss of trust in the judiciary as a forum for constitution-making dispute resolution.

\section{Constitution-Making Dispute Resolution Mechanism: An Afterthought}

Modern constitution-making initiatives must embrace two dimensions which are mutually reinforcing: substance and process. While substance is among others, about the exercise of power by the organs of state and perhaps the bill of rights, process fosters legitimacy of and fidelity to the constitution (Ghai, 2012; Regassa, 2010). In our view, a credible constitution-making dispute resolution mechanism is central to the whole enterprise of constitution-making and should be effectively and explicitly entrenched in the constitution-making process.

The statutory foundation of the 2010 constitution-making exercise was the Constitution of Kenya Review Act 2008 (the 'Review Act'). The Review Act demonstrated its drafters' intention of reforming the country's political governance by guaranteeing public participation in decision-making, a clear departure from the past purist representative governance system in which power was essentially concentrated in the presidency.

A principal omission of the Review Act was that it did not provide for a dispute resolution mechanism to tackle questions of substance or process in the envisaged constitution. That was a major omission considering that after the hotly disputed 2007 election results, Raila Odinga and his Orange Democratic Movement (ODM) party rejected presidential election dispute settlement (KNDR, 2009). It is for this reason that Parliament enacted the Constitution of Kenya (Amendment) Act 10, 2008.

The above Act provided for the establishment of the Interim Independent Constitutional Dispute Resolution Court (IICDRC). The Court was different from the High Court which was created under section 60 of the Constitution. By virtue of the Amendment Act, a new section 60A establishing the IICDRC was inserted in the Constitution. Section 60A (1) provided that "notwithstanding section 60, there shall be an Interim Independent Constitutional Dispute Resolution Court which shall have exclusive original jurisdiction to hear and determine all and only matters arising from the constitutional review process". We are of the view that as in South Africa and as more elaborated in the case of Certification of the Constitution of the Republic of South Africa (1996), section 60A should have been bolstered by principles or guidelines the Court would apply in determination of disputes bearing in mind that it was an ad hoc court of first and final instance. The Court had to be established within 24 months of the amendment.

Before the IICDRC had been operationalized, there was a legal void on how disputes pertaining to the constitutional review process could be determined. However, the law was laid down by the High Court in the case of Bishop Joseph Kimani and 2 Others $v$ The Attorney-General and 2 Others (2009). In that case, the applicants approached the High Court for alleged contravention of their fundamental rights and freedoms enshrined in sections 70 , 72,75 and 78 of the Constitution. Their main contention was that the CoE was in no position to determine for Kenyans what amounted to matters contentious or not contentious based on the Wako and Bomas Draft Constitutions. Their main contention was that constitution-making process was an exercise for all Kenyans to be engaged in.

The Court dismissed the respondents' objections on want of jurisdiction as the IICDRC was the right forum. The High Court ruled that as the IICDRC had not been operationalized, it had to determine the dispute in the exercise of its original and inherent jurisdiction vested in the Court by section 60 of the Constitution. In particular, it observed that section 60A could not be applied to bar the applicants from accessing justice as that was their legitimate expectation (Bishop Kimani, 2009 pp. 13).

Before the 24 months for the operationalization of the Court lapsed, the IICDRC judges were appointed and swornin on 15 January 2010 (State House, 2010). This was over one year of the establishment of the Court. The Court was composed of nine judges, six of whom were Kenyans and three expatriate judges (State House, 2010). The foregoing examination of the road leading to the establishment of the IICDRC provides some valuable lessons in the 2010 constitution-making process.

Firstly, the legislature and other key parties including the Kofi Anan-led Kenya National Dialogue and Reconciliation (KNDR) failed to grasp the importance of deciding on and entrenching in the Review or other Act, dispute 
settlement mechanisms. This should not have happened given the irreverent state of the country's judiciary as discussed above. Secondly, ample time was lost before the operationalization of the IICDRC. The inordinate delay frustrated petitioners who were denied access to that court such that the High Court as seen in the case of Bishop Kimani above was ready to intervene. As discussed below, time lost in the operationalization of the IICDRC might have denied it the opportunity of fully examining the jurisprudential soundness of some of the submissions made by the respondents especially those touching on sovereignty of parliament and the political question doctrine. The court had to work hastily as the date set for referendum on the draft constitution had almost arrived.

\section{IICDRC Decisions: A Mixed Bag}

After the inauguration of the IICDRC bench, the High Court's jurisdiction was exhausted and it could therefore not deal with the Bishop Kimani or any other constitutional review cases. This was held by the High Court in the case of Mary Ariviza v Interim Independent Electoral Commission and Another (2010). In that case, the applicants had sought, among others, an order setting aside the results of the referendum. The Court held that it concurred with the judgment in the Bishop Kimani case on the right of access to the Court and its jurisdiction to entertain the application, notwithstanding section 60A.However, the Court held that circumstances had changed. Since the decision in the Bishop Kimani case, the IICDRC had become functional. The Court's jurisdiction had accordingly been terminated (Ariviza, pp.22). It is now appropriate to examine some of the key decisions of the IICDRC touching on the review process.

Within the short life of the IICDRC, some key decisions with a major bearing on the constitutional review process were delivered three of which are examined in this paper. They are Bishop Joseph Kimani and 2 Others $v$ The Attorney General and 2 Others (IICDRC) (2010); Mary Ariviza and Another v The Attorney-General and 3 Others (IICDRC) (2010) and Andrew Omtata Okoiti and 5 Others v The Attorney-General and 2 Others (IICDRC) (2010).

The driving force behind the case of Bishop Kimani seems to have been the orders made by the High Court in the case of Jesse Kamau and 25 Others v Attorney General and Another (2010). The key issue in the case was the legitimacy of the Kadhis' (Islamic Courts) which have been in existence long before independence. The applicants, all Christians, approached the High for it to make orders that section 66 of the old Constitution, which entrenched Kadhis' Courts, was inconsistent with sections 70,78,79, 80 and 82 of the same Constitution.

The applicants' contention was that their rights to equal protection of the law were infringed by section 66 as a particular religion was given constitutional recognition. Most importantly, they contended that section 66 was a hidden agenda to introduce, advance, propagate and promote Islam in Kenya and Africa as a whole under what they termed the "Abuja Declaration". After examining a number of constitutions especially those of the USA and South Africa, the Court observed that those constitutions, almost without exception, prohibit direct or indirect discrimination of an individual on the basis of religion among other grounds (Jesse Kamau, 2010).

In making the declarations sought, the Court recommended alterations to the Constitution so as to remove the conflict. It observed that section 66 had "the effect of furthering one faith as against others" (Jesse Kamau, 2010 pp.87). This interpretation was wrong because a constitution cannot be said to be in conflict with itself. As the IICDRC observed in the case of Bishop Kimani, the High Court's view that the Constitution was in conflict with itself failed to meet established principles of constitutional interpretation (Bishop Kimani, 2010).

The petitioners in the case of Bishop Kimani were concerned about the retention of the Kadhis' Courts in the proposed Draft Constitution. Their main prayer was for the referendum to be postponed to allow for more dialogue on the undefined "contentious issues" through the Committee of Experts (CoE) and other review organs; the Review Act be amended to provide for the revision of the proposed Constitution and to subject the Kadhis' Courts to audit by the people of Kenya and a declaratory order that the inclusion of the Kadhis' Courts in the proposed Constitution was contemptuous in view of the High Court's decision in the case of Jesse Kamau. They specifically pleaded with the Court to expunge those provisions in the proposed Constitution which, as in the old Constitution, established the Kadhis' courts (Bishop Kimani, 2010).

The IICDRC dismissed the petition on the ground that the orders sought did not exist in law. In particular, the Court noted that the CoE had consulted widely and had exercised its discretion appropriately in the execution of its statutory mandate especially in determining the contentious issues. The Court noted that it was not bound by the decision of the High Court in the case of Jesse Kamau. Most importantly, the Court held that no one provision of a constitution is superior to another. It observed that "the Constitution as a supreme law is a wholesome document, it is a living document and operates through all the provisions, not one", (Bishop Kimani, 2010 pp.13).

In the case of Mary Ariviza, (2010) the petition to the IICDRC was for a scrutiny and recount of all the ballot papers due to many alleged irregularities; independent audit of the referendum results; declaration that the referendum results 
were null and void and the relevant Gazette Notice No 1019 of 23 August 2010 that published the final results of the referendum be struck out. The petitioner's difficulties, which were insurmountable and therefore the dismissal of the petition, were mainly her failure to comply with the Review Act. In the first place, she had filed the petition after 14 days of the publication of the referendum results. She had not also deposited the requisite deposit of Two Million Shillings as security for costs. Indeed, no such money had been deposited with the Court by the time it completed writing the ruling (Mary Ariviza, 2010).

The case of Andrew Omtata Okoiti and 5 Others $v$ The Attorney-General and 2 Others (2010) was described by the IICDRC as "fairly profound litigation" (Andrew Omtata, 2010 pp.1). It is argued that the constitutional issues involved were indeed profound given Kenya's rough terrain of constitution-making. The importance of the issues was reinforced by the fact that the petitioners attacked some of the key organs mandated to drive the constitution-making process. These were the Attorney-General; the CoE and the Interim Independent Electoral Commission (IIEC).

The cardinal issues in the case of Andrew Omtata were the Attorney-General's alteration of the draft Constitution; the role of the people in constitution-making and the composition and manner in which the CoE proceeded to determine "contentious issues" in the Wako and Bomas Draft Constitutions. In addition, the Court had to determine the locus standi of the petitioners. The respondents' argument was that the petitioners had no locus standi to get orders which would have enormous impact on 40 million Kenyans who had not approached the Court and for whom the petitioners were not acting (Andrew Omtata, 2010, pp.4). Further, one of the petitioners was residing in the diaspora, a University Professor in the USA and was therefore not qualified to participate in the referendum as he was not a registered voter.

Also crucial was the question whether the IICDRC had the jurisdiction to grant the orders sought. The point was raised by the respondents who contended that the role of the Court was to ensure that the constitutional review process was within the law. They reasoned that a contrary interpretation of section 60A would have amounted to the Court interfering with the principal doctrine of separation of powers. They averred that the Court could not usurp the role of Parliament which had vested various review functions to specific institutions.

Their other main argument was that the Court's hands were tied as the various aspects of the review process had become functus officio. They also averred that each of the review organs had timeously discharged its responsibilities and that the petitioners had delayed in approaching the Court. All that was pending in the road-map to a new constitution, they added, was the voting in the referendum. The Court dismissed the claims against the alleged improprieties of the review bodies. It held that the Attorney-General only corrected editorial errors which did not impact fundamentally on the Draft. On the $\mathrm{CoE}$, the Court held that each of the experts had satisfied the minimum requirements for his or her appointment as provided for in section 10(1) of the Review Act. This included proven experience and knowledge in comparative and constitutional law, human rights, governance, ethics and accountability and women and gender issues among others.

The Court also held that the CoE consulted widely on the contentious issues for the stipulated duration in which the petitioners did not raise any concerns to the $\mathrm{CoE}$. There was no evidence that the $\mathrm{CoE}$ approached wrong considerations in its determination of what amounted to "contentious" issues. The Court also noted that the petitioners had not complained to Parliament or other relevant authority.

In the course of determining the various issues before it, the IICDRC made what we consider progressive pronouncements of the law from the uncomfortable perspective of Kenya's human rights jurisprudence. It is argued that although the IICDRC was an ad hoc and transitional judicial institution under the broader subject of transitional justice, this decision has important place in Kenya's constitutional jurisprudence. On the question of what the Court termed the weighty issue of its jurisdiction because of the long road of the review process as the only handle pending was the referendum, the Court held that it had to stamp its authority "in pronouncing and declaring rights in whatever circumstances" (Andrew Omtata, 2010 pp.5). It also added that it was vested with jurisdiction as the petitioners had approached the Court alleging breach of fundamental rights.

On the petitioners' lack of locus standi as they had prayed for orders which could affect the rest of Kenyans, the Court held that in matters of constitutional review, the Court could not close its doors on any person acting in good faith. The importance of this opinion was that the Court was confirming emerging Kenyan jurisprudence of a relaxed interpretation of the doctrine of locus standi by the Kenyan Courts. It is submitted that it was on the basis of the new approach to locus standi that the Court made a rare order in Kenya's judicial history. In holding that qualified citizens in the diaspora had a right to vote as enshrined in the Universal Declaration of Human Rights and the International Covenant on Civil and Political Rights, the Court made "appropriate modifications to section 43 of the Constitution" (Andrew Omtata, 2010 pp.20). Section 43 set out the requirements to be met for a person to be registered as a voter in elections to the National Assembly and in elections of the President. In arriving at this finding, the Court noted the economic contribution to the nation by persons in the diaspora as elucidated by the CCSA in the case of Willem 
Stephanus Richter v Minister of Home Affairs and Others (2009). The CCSA also noted the "civic-mindedness" of these South Africans which the democratic system benefits (Willem Staphanus, 2009).

The boldness of the IICDRC in making orders for "modifications" to the Constitution so as to enforce the fundamental right of the citizens not residing in the country in order for them to participate in a referendum is indeed commendable. It seems to confirm the democratic importance of one's vote, in what South Africa's Sachs J termed in the case of August $v$ Electoral Commission, (1999) as a badge of dignity and personhood. However, as this right was pronounced on 2 August 2010, it was too late for it to be exercised under Kenya's 2010 referendum.

The main paradox of Andrew Omtata decision was that the Court's approach to section 43 clearly contradicted its reasoning in not granting orders which would have interfered with what the review organs had done under the Review Act. We find the following remarks immensely disturbing:

\begin{abstract}
...the doctrine of parliamentary sovereignty and separation of powers does not allow this Court to undo that which parliament has done. This doctrine is about the relationship between those who create the Acts (Parliament) and those who must apply them (courts). When Dicey published The Law of the Constitution (1885), he identified parliamentary sovereignty as meaning that, Parliament has, under the English Constitution, the right to make or unmake any law whatever; and further that no person or body is recognized by the law of England as having a right to override or set aside the legislation of Parliament. What this means is that as long as an Act has passed through Parliament and received Presidential Assent (Royal in the case of the UK), judges will not argue whether or not a statute should or should not exist but will merely try to apply the statute (Andrew Omtata, 2010 pp.22).
\end{abstract}

In our view, the IICDRC fundamentally erred in holding that its hands were tied by the Review Act due to the doctrines of parliamentary sovereignty and of separation of powers. The court did not take into account the overarching philosophy of sovereignty of the people of Kenya which underpinned the constitution-making exercise as enshrined in the Review Act. Secondly, Kenyan courts are bound by the rule of law and supremacy of the constitution, which are undoubtedly larger than the doctrine of parliamentary sovereignty or any other legal doctrine. It is difficult to comprehend how the Court could not recognize and apply section 3 of the Constitution which spelt out the supremacy of the Constitution. As already observed, the IICDRC had suggested amendments to the Constitution and "read in" so as to enforce the right of those in the diaspora to vote. It is argued that the said interpretation was the right view of the law as the two doctrines have to be understood within the celebrated doctrines of constitutional supremacy and the rule of law.

By the rule of law, we mean a departure from positivistic jurisprudence to a substantive and formidable legal concept mainly encompassing reasonableness, natural justice and human rights, what may also be referred to as a 'thick' conception of the rule of law doctrine (Raz, 1972). This approach also poses the question of the fairness of a decision or rule (Ringer, 2007). In any case, if the IICDRC could interfere with the doctrine of separation of powers by making alterations to the Constitution on what we consider a 'thick' view of the rule of law, it could have declared its power to overturn the Review Act. Our view is that in statutory interpretation, the task of the court, especially a pivotal one like the IICDRC cannot merely be the application of a statute as opined by the ICDRC in the case of Andrew Omtata.

Connected to the Court's view of the doctrines mentioned above was the "political question" doctrine. It observed that "the political question doctrine come in handy where larger constitutional questions touching on parliament and the executive are at issue" (Andrew Omtata, 2010 pp.25). The "larger" constitutional question, it would appear, was the postponement of the referendum. It is argued that the postponement of the referendum was not weighty enough to deny the petitioners the right to a full examination of the issues canvassed before the Court. In any event, there was a precedent. In the case of Njoya \& 6 Others v Attorney-General \& 6 Others (2008), the High Court stopped Parliament of Kenya from making a constitution because the people, where the constituent power rests, had not been given the right to a referendum by the review laws then prevailing. It held that Parliament had "no power under the provisions of section 47 of the Constitution to abrogate the Constitution and or enact a new one in its place" (Njoya, 2009 pp.694). Stopping a referendum is clearly a political question and just as in the case of Njoya, the IICDRC should have been undeterred by the political question doctrine.

Although the IICDRC held that the petition lacked merit except as regards the right of those in the diaspora to vote, it adopted an erroneous interpretation and application of the doctrines of separation of powers and sovereignty of parliament. Its approach must have obscured and swayed the pendulum of justice against the petitioners. The foregoing misguided approach of the IICDRC combined with delay in the operationalization of the court meant that opportunity was lost for a thorough judicial examination of the legitimacy of the entire constitution-making process. 


\section{Conclusion}

This article has examined the nature of Kenya's 2010 constitution-making dispute resolution mechanism. Ordinarily, such a mechanism would be in the hands of the judiciary. However, due the woes facing the country's judiciary under the old constitutional order and in view of the importance of the exercise to the people of Kenya, a different route had to be taken. Before then, the assumption at the time must have been that under the Review Act, disputes could be lodged in the High Court. It later became clear that the judiciary could not be trusted with dispute settlement and a new dispute resolution strategy had to be found. The problem was that the new approach which commenced with constitutional amendment to entrench the IICDRDC was in our view an afterthought with the result that the High Court felt aggrieved and was ready to intervene, a pronouncement which must have triggered the promulgation of the IICDRC. In addition, judges of the Court were sworn-in after fourteen months of the establishment of the Court and thus the anxiety expressed by the High Court.

The article has also examined key decisions of the IICDRC. It has been seen that while the court made some progressive pronouncements especially on the right of Kenyans in the diaspora to vote, there was grave misdirection and misinterpretation of the law especially sovereignty of parliament and the political question doctrines. The article has demonstrated that the court should have subjected these doctrines to a non-formalistic and "thick" rule of law doctrine reinforced by section 3 of the Constitution which provided that the Constitution was the supreme law of the land. The court denied itself an opportunity to investigate the legitimacy of the constitution-making process by holding that it could not question the soundness of the Review Act because its hands were tied by the doctrine of sovereignty of parliament.

The article recommends that in constitution-making environment in which there is mistrust of the judiciary as an arbiter of constitution-making grievances, dispute resolution mechanism must decisively and timeously be agreed upon at the time of the commencement of the process. If the judiciary is denied jurisdiction in such matters, there should be no delay in operationalization of an ad hoc court so as to mitigate the anxiety and confusion found in Kenya before the promulgation of the IICDRC. Statutory provisions establishing the court should be as elaborate as possible so as to avert any discomfiture and for the arbiter(s) of constitution-making or reforms dispute to fully familiarize themselves with their jurisdiction. Guidelines or principles should be provided on the philosophy underpinning the settlement of disputes, a crucial factor especially if the arbiter(s) come from different jurisdictions as was the case with the IICDRC. If disputes are to be determined by the judiciary, enough safeguards in particular wide consultation must be put in place to mitigate real or perceived claims against the absence of independence of the courts and accusations of bias or incompetence.

\section{References}

\section{Books}

Mutunga, W., 1999. Constitution-Making from the Middle: Civil Society and Transition Politics in Kenya, 1992-1997. Nairobi and Harare: Sareat and Mwengo.

Throup, D., and Harnsby, C., 1998. Multi-Party Politics in Kenya: The Kenyatta and Moi States and the Triumph of the System in the 1992 Election. London: Villiers Publications.

Wanyande, P., Omosa, M., Ludeki, L., 2007. Governance and Transition Politics in Kenya. Nairobi: University of Nairobi Press.

Mejia, R., 1995. The Conscience of Society: The Social Teaching of the Catholic Bishops of Kenya: 1960-1995. Nairobi. Paulines Publications Africa.

\section{Journal articles}

Hoexter, C "The Principle of Legality in South African Administrative Law", (2004) Macquire Law Journal 165-185.

M'Inoti, K "The Impact of English Legal Principles on Constitutional Litigation in Kenya," (2003) University of Nairobi Law Journal 195208.

Mutua, M "Justice under Siege: The Rule of Law and Judicial Subservience in Kenya," (2001) Human Rights Quarterly 96-118.

O' Connor "Vindicating the Rule of Law," (2003) Chinese Journal of International Law; 1-10.

Kruger, $R$ "The South African Constitutional Court and the Rule of Law: The Masethla Judgment, A Cause for Concern? (2010) 13:3 Potchefstroom Electronic Law Journal 468-508.

Kuria, K and Vazquez, A "Judges and Human Rights: The Kenyan Experience," 35 (1991) Journal of African Law 142-173.

Raz, J "Legal Principles and the Limits of Law," (1971) Yale Law Journal 823-854

Ringer, $T$ "Development, Reform, and the Rule of Law: Some Prescriptions for a Common Understanding of the "Rule of Law" and its Place in Development Theory and Practice," (2007) Yale Human Rights and Development Law Journal 178-208.

Taitel, R "Transitional Justice Genealogy," (2003) Harvard Human Rights Journal 69-94. 
Regassa, $T$ "The Making and Legitimacy of the Ethiopian Constitution: Towards Bridging the Gap between Constitutional Design and Constitutional Practice," (2010) 23:1 Afrika Focus 85-118.

\section{Cases}

Kenya

Andrew Omtata Okoiti and 5 Others v The Attorney-General and 2 Others (IICDRC) Constitutional Petition 3 of 2010 [2010] Eklr.

Bishop Joseph Kimani and 2 Others v The Attorney-General and 2 Others High Court at Mombasa Petition No 669 of 2009 (unreported). Bishop Njenga Kimani and 2 Others v The Attorney General and 2 Others (IICDRC) Constitutional Petition 4 of 2010 [2010] eKLR 1. Jesse Kamau and 25 Others v Attorney General and Another [2010] eKLR 1.

Mary Ariviza and Another v The Attorney-General and 3 Others (IICDRC) Constitutional Petition 7 of 2010 [2010] eKLR 1.

Njoya and 6 Others v Attorney-General and 6 Others (2008) 2 KLR 658 (EP).

South Africa

August and Another v Electoral Commission and Others 1993 (3) SA 1.

Certification of the Constitution of the Republic of South Africa 1996(4) SA 744 (CC).

Justice Alliance of South Africa v President of the Republic of South Africa and Others 2011 (SA) 388 (CC).

Willem Stephanus Richter v Minister of Home Affairs 2009 (3) SA 615 (CC).

\section{Reports}

Report of the Committee of the Administration of Justice (Kwach Report), 1998.

Report of the Integrity and Anti-Corruption Committee of the Judiciary of Kenya (The Ringera Report). 2003.

International Commission of Jurists, Kenya: Judicial Independence, Corruption and Reforms, 2005.

Kenya National Dialogue and Reconciliation Monitoring Project, 2009.

State House, President Kibaki Assures Kenyans on Constitution, 15 January 2010. 